\title{
Preoperative CYFRA 21-1 and CEA as Prognostic Factors in Patients with Stage I Non-Small Cell Lung Cancer
}

\author{
External Validation of a Prognostic Score
}

\author{
Florian Blankenburg ${ }^{a}$ Rudolf Hatz ${ }^{b}$ Dorothea Nagel ${ }^{a}$ Donna Ankerst ${ }^{d}$ \\ Judith Reinmiedl ${ }^{c}$ Christine Gruber ${ }^{a}$ Dietrich Seidel ${ }^{a} \quad$ Petra Stieber $^{a}$ \\ ${ }^{a}$ Institute of Clinical Chemistry and ${ }^{b}$ Department of Surgery, University Hospital of Munich-Großhadern, Munich, \\ and ${ }^{\mathrm{C} C e n t e r}$ for Pneumology and Thoracic Surgery, Asklepios Clinics, Gauting, Germany; ${ }^{\mathrm{d}}$ Institute of \\ Epidemiology and Biostatistics, University of Texas Health Science Center at San Antonio, San Antonio, Tex., USA
}

\section{Key Words}

CEA $\cdot$ CYFRA 21-1 $\cdot$ External validation $\cdot$ Non-small cell lung cancer $\cdot$ Tumor markers

\begin{abstract}
Objective: To validate the prognostic value of preoperative levels of CYFRA 21-1, CEA and the corresponding tumor marker index (TMI) in patients with stage I non-small cell lung cancer (NSCLC). Methods: Two hundred forty stage I NSCLC patients (80 in pT1 and 160 in pT2; 100 squamous cell carcinomas, 91 adenocarcinomas, 32 large-cell carcinomas, 17 with other histologies; 171 males and 69 females) who had complete resection (R0) between 1986 and 2004 were included in the analysis. CYFRA 21-1 and CEA were measured using the Elecsys system (Roche) and AxSym-System (Abbott), respectively. Univariate analysis was performed using the Kaplan-Meier method to identify potential associations between survival and age, gender, CYFRA 21-1, CEA and TMI. Results: Overall 3- and 5-year survival rates were 74 and $64 \%$, respectively. Male gender $(p=0.0009)$ and age $>70$ years ( $p=0.0041$ ) were associated with a worse prognosis; there were no differences between pT1 and pT2 nor be-
\end{abstract}

\section{KARGER}

Fax +41613061234 E-Mail karger@karger.ch www.karger.com
(C) 2008 S. Karger AG, Basel

$1010-4283 / 08 / 0294-0272 \$ 24.50 / 0$

Accessible online at:

www.karger.com/tbi tween histological subtypes. Three-year survival was $72 \%$ for CYFRA $21-1$ levels $>3.3 \mathrm{ng} / \mathrm{ml}$ versus $75 \%$ for levels $\leq 3.3$ $\mathrm{ng} / \mathrm{ml}, 71 \%$ for CEA $>6.7 \mathrm{ng} / \mathrm{ml}$ versus $75 \%$ for CEA $\leq 6.7 \mathrm{ng} /$ $\mathrm{ml}$ (both $\mathrm{p}$ values $>0.05$ ). Corresponding 5-year survival rates were near $64 \%$ both for patients with CYFRA 21-1 values above and below the cutoff ( $3.3 \mathrm{ng} / \mathrm{ml}$ ), and 49 and $66 \%$ for patients with values above and below the CEA cutoff (6.7 $\mathrm{ng} / \mathrm{ml}$ ), respectively (both $\mathrm{p}$ values $>0.05$ ). Overall survival did not vary in the different TMI risk groups $(p=0.73)$. Conclusions: In this cohort of early-stage NSCLC patients, male gender and age $>70$ years were associated with a worse outcome, but elevated levels of CEA and CYFRA 21-1, and TMI risk were not.

Copyright $\odot 2008$ S. Karger AG, Basel

\section{Introduction}

With over one million deaths in 2002 [1] and over 160,000 in the United States (US) alone in 2005 [2], lung cancer remains one of the leading causes of death worldwide. Resection is still the only therapy recommended to treat stage I non-small cell lung cancer (NSCLC) by the 
International Union against Cancer [3, 4], with only few studies demonstrating a potential benefit of adjuvant platinum-based chemotherapy for stage IB $[5,6]$. Therefore, a current challenge in NSCLC treatment is to identify patients that might benefit from more aggressive therapy versus those that may be overtreated. In addition to standard risk factors, in a study by Muley et al. [7] elevated levels of oncological biomarkers (CEA and CYFRA 21-1) were associated with a worse outcome in stage I NSCLC patients. Muley et al. [7] therefore proposed a prognostic score, the tumor marker index (TMI), comprising normalized CEA and CYFRA 21-1 values, and defined three prognostic groups based on the increasing mortality risk according to the TMI score. They concluded that stage I NSCLC patients in the group with the worst prognosis according to the TMI might benefit from further therapy beyond surgery alone. Such a prognostic score is desirable for stage I NSCLC patients since even in patients at this early stage, prognosis is poor, with a 5 -year survival rate of approximately $60 \%$. Against this backdrop, the aim of this study was to verify the results reported by Muley et al. [7] and to validate the TMI in an independent cohort of patients.

\section{Patients and Methods}

\section{Patients}

Preoperative data and clinical follow-up of 240 patients diagnosed with NSCLC in pathological stage I and treated between 1986 and 2004 by complete resection (R0) at the University of Munich Hospital in Grosshadern, Munich, were included in the retrospective study. In addition to $\mathrm{pT}$ stage and histology, data from CEA and CYFRA 21-1 levels determined within 30 days prior to surgery were required for inclusion in the study. Patients with known malignancies from other organs were excluded. The diagnosis of lung cancer was confirmed by pathological examination and classified according to the World Health Organization criteria [8]. Postoperative tumor stage was defined by the revised International System for staging of Lung Cancer [9].

\section{Tumor-Associated Antigens}

Blood samples were taken within 30 days prior to surgery. CEA was determined with an Abbott AxSYM Analyzer (Abbott Laboratories, Chicago, Ill., USA) using the microparticle enzyme immunoassay. Starting from 1992, CYFRA 21-1 was routinely assessed by an Elecsys kit (Roche Diagnostics, Mannheim, Germany) in all patients with suspected lung cancer. In patients treated before 1992 , serum samples stored at $-80^{\circ} \mathrm{C}$ were used for CYFRA 21-1 determination.

\section{TMI}

In the study by Muley et al. [7], CYFRA 21-1 and CEA were both assessed by the Cobas Core System of Roche Diagnostics. The TMI was defined by taking the geometric mean of normal- ized values of CYFRA 21-1 and CEA, where normalization was performed by dividing individual marker values by corresponding diagnostic cutoff points, i.e. $3.3 \mathrm{ng} / \mathrm{ml}$ for CYFRA $21-1$ and 5.0 $\mathrm{ng} / \mathrm{ml}$ for CEA:

$$
\mathrm{TMI}=\sqrt{\frac{\text { CYFRA } 21-1 \mathrm{ng} / \mathrm{ml}}{3.3 \mathrm{ng} / \mathrm{ml}} \cdot \frac{\text { CEA ng/ml }}{5.0 \mathrm{ng} / \mathrm{ml}}}
$$

In this study, TMI was calculated accordingly with the exception of using $4.0 \mathrm{ng} / \mathrm{ml}$ as the normalizing factor for CEA due to the different assay system; this was not necessary for CYFRA 21-1 since the Elecsys system employs the same diagnostic cutoff point.

\section{Statistical Analysis}

Univariate Kaplan-Meier survival curves and rates were calculated, with statistical significance assessed using the log-rank test. To be able to compare our results with those of Muley et al. [7], the cutoff points for age and CYFRA 21-1 were 70 years and $3.3 \mathrm{ng} / \mathrm{ml}$, respectively, and the same three risk groups for TMI were assessed: $<0.48$ for group A (low risk), $0.48-0.83$ for group $\mathrm{B}$ (intermediate risk) and $>0.83$ for group $\mathrm{C}$ (high risk). Due to the use of different CEA assays, the cutoff point for CEA was 6.7 $\mathrm{ng} / \mathrm{ml}$ as opposed to $9.8 \mathrm{ng} / \mathrm{ml}$ in the study by Muley et al. [7] in order to achieve the same percentage of patients with CEA values above the cutoff point (13\%). In addition, for CYFRA 21-1 and CEA, all values between the 5th and 95th percentiles were evaluated as potential cutoff points using the log-rank test, with statistical significance being assessed at the down-adjusted level of $\alpha=$ 0.0017 , as recommended for multiple testing [10]. All other statistical tests were performed at the two-sided $\alpha=0.05$ level of statistical significance. All analyses were performed using the statistical package of SAS (version 9.1, SAS, Cary, N.C., USA).

\section{Results}

The characteristics of the 240 study patients and those of the study by Muley et al. [7] are given in table 1. Their study comprised 153 stage I patients, all treated surgically (R0) between 1996 and 1998 at the Clinic for Thoracic Diseases of the University of Heidelberg. Table 1 shows that patient characteristics did not differ between both studies (all $\mathrm{p}>0.05$ ).

The 3- and 5-year overall survival rates did not significantly differ between our (74 and 64\%, respectively), and their study (75 and 58\%, respectively; table 2). Median survival of female patients was 13 years, and in males survival was statistically significantly shorter. Age $>70$ years was also associated with a poorer outcome. There were neither statistically significant differences in survival between $\mathrm{pT} 1$ and $\mathrm{pT} 2$ stage patients or between histological subtypes nor between adenocarcinomas and squamous cell carcinomas, in agreement with the study by Muley et al. (table 2). 
Table 3 lists tumor marker levels in their and our study groups, and in our patients according to $\mathrm{pT}$ stage. CYFRA 21-1 levels were similar in both studies, whereas CEA levels were lower in our study due to the different assay system used. Marker levels were higher in pT2 compared to pT1 stage patients.

Table 1. Characteristics of the lung cancer patients from Munich and Heidelberg

\begin{tabular}{lccc}
\hline Characteristics & $\begin{array}{l}\text { Munich } \\
(\mathrm{n}=240)\end{array}$ & $\begin{array}{l}\text { Heidelberg } \\
\left(\mathrm{n}=153^{\mathrm{a}}\right)\end{array}$ & $\begin{array}{l}\mathrm{p} \\
\text { value }^{\mathrm{b}}\end{array}$ \\
\hline Age, years & & & \\
$\quad$ Mean & 63.6 & 64.8 & \\
$\quad$ Range & $23-81$ & $32-78$ & \\
Male & $171(71.2 \%)$ & $121(79.1 \%)$ & 0.08 \\
Female & $69(28.8 \%)$ & $32(20.9 \%)$ & \\
Squamous cell carcinoma & $100(41.7 \%)$ & $59(38.6 \%)$ & \\
Adenocarcinoma & $91(37.9 \%)$ & $75(49 \%)$ & 0.07 \\
Large-cell carcinoma & $32(13.3 \%)$ & $10(6.5 \%)$ & \\
Other histologies & $17(7.1 \%)$ & $9(5.9 \%)$ & \\
pT1 stage & $80(33.3 \%)$ & $51(33.3 \%)$ & 1.00 \\
pT2 stage & $160(66.6 \%)$ & $102(66.6 \%)$ & \\
Died during follow-up & & & \\
$\quad$ Total & $111(46.3 \%)$ & not reported & \\
$\quad$ Male & $88(36.7 \%)$ & not reported & \\
$\quad$ Female & $23(17 \%)$ & not reported & \\
\hline
\end{tabular}

${ }^{\text {a }}$ Extracted from Muley et al. [7].

${ }^{b} \chi^{2}$ test for differences between the two studies.
Three- and 5-year survival rates for preoperative CYFRA 21-1 and CEA levels of patients grouped according to the cutoff points are described in table 4 . Based on these cutoff points, neither CYFRA 21-1 nor CEA was associated with survival ( $\mathrm{p}=0.67$ for CYFRA $21-1$ and $\mathrm{p}=$ 0.09 for CEA). In contrast, a significant association between CYFRA 21-1 and 3-year survival was reported in the study by Muley et al. $(\mathrm{p}=0.015)$, with a markedly lower 3-year survival rate for patients with CYFRA 21-1 levels above the cutoff point compared with this study (table 4).

TMI was calculated for all of our patients according to the risk groups described by Muley et al. [7]. In their study, the low-, intermediate- and high-risk groups com-

Table 3. Distribution of biomarkers ( $\mathrm{ng} / \mathrm{ml}$ )

\begin{tabular}{|c|c|c|c|c|}
\hline & \multicolumn{2}{|c|}{ Munich $(\mathrm{n}=240)$} & \multicolumn{2}{|c|}{ Heidelberg $(\mathrm{n}=153)$} \\
\hline & $\mathrm{n}$ & $\begin{array}{l}\text { median (5th-95th } \\
\text { percentiles) }\end{array}$ & $\mathrm{n}$ & $\begin{array}{l}\text { median (5th-95th } \\
\text { percentiles) }\end{array}$ \\
\hline \multicolumn{5}{|c|}{ CYFRA 21-1 } \\
\hline All & 240 & $1.8(0.9-7.5)$ & 141 & $1.8(0.9-8.0)$ \\
\hline pT1 & 80 & $1.2(0.5-3.2)$ & & not reported \\
\hline pT2 & 160 & $2.6(0.5-13.2)$ & & not reported \\
\hline \multicolumn{5}{|l|}{ CEA } \\
\hline All & 240 & $2.7(0.9-13.8)$ & 153 & $3.5(1.1-21.0)$ \\
\hline pT1 & 80 & $2.6(0.9-8.6)$ & & not reported \\
\hline pT2 & 160 & $2.8(0.9-25.5)$ & & not reported \\
\hline
\end{tabular}

Table 2. Univariate analysis of survival

\begin{tabular}{|c|c|c|c|c|c|}
\hline & \multirow{2}{*}{$\begin{array}{l}\text { Median } \\
\text { survival } \\
\text { months }\end{array}$} & \multicolumn{3}{|l|}{ Munich } & \multirow{2}{*}{$\begin{array}{l}\text { Heidelberg } \\
\text { p value } \\
\text { log-rank test }\end{array}$} \\
\hline & & $\begin{array}{l}5 \text {-year } \\
\text { survival, \% }\end{array}$ & $\begin{array}{l}\text { 3-year } \\
\text { survival, \% }\end{array}$ & $\begin{array}{l}\mathrm{p} \text { value } \\
\text { log-rank test }\end{array}$ & \\
\hline Overall & 110 & 63.9 & 74.4 & & \\
\hline Sex & & & & $<0.001$ & 0.029 \\
\hline Male & 86 & 58.0 & 70.4 & & \\
\hline Female & 156 & 76.7 & 83.5 & & \\
\hline Age & & & & 0.004 & 0.026 \\
\hline$<70$ years & 125 & 69.6 & 77.8 & & \\
\hline$>70$ years & 58 & 47.6 & 64.1 & & \\
\hline Histological type & & & & 0.16 & 0.18 \\
\hline Squamous cell carcinoma & 105 & 64.5 & 72.0 & & \\
\hline Adenocarcinoma & 125 & 63.2 & 76.7 & & \\
\hline Large cell carcinoma & 61 & 55.6 & 65.4 & & \\
\hline Other histology & 123 & 77.9 & 92.9 & & \\
\hline Pathological stage & & & & 0.146 & 0.14 \\
\hline pT1 & 125 & 71.5 & 81.1 & & \\
\hline pT2 & 96 & 59.9 & 70.9 & & \\
\hline
\end{tabular}




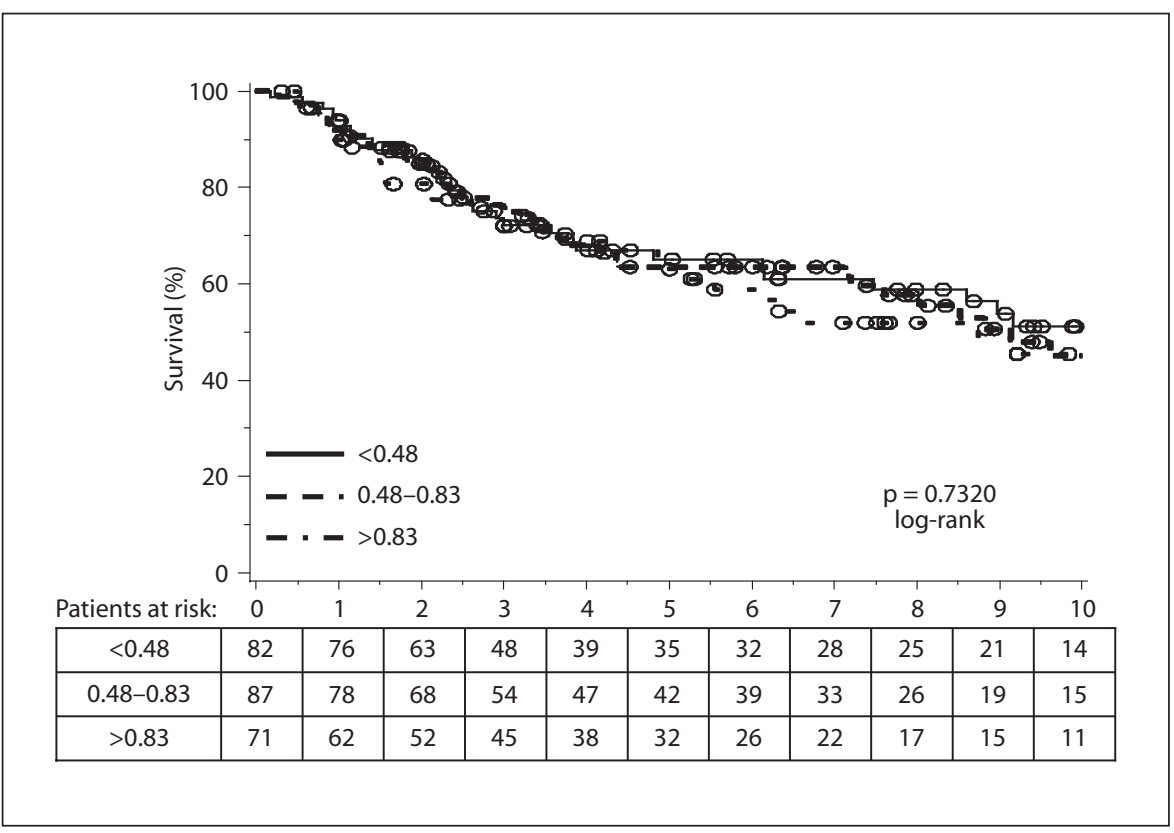

Fig. 1. Survival curves by TMI.

Table 4. Univariate analysis of survival and biomarkers (ng/ml)

\begin{tabular}{|c|c|c|c|c|c|c|}
\hline & \multirow{2}{*}{$\begin{array}{l}\text { Median } \\
\text { survival } \\
\text { months }\end{array}$} & \multicolumn{3}{|l|}{ Munich } & \multicolumn{2}{|l|}{ Heidelberg } \\
\hline & & $\begin{array}{l}\text { 5-year } \\
\text { survival, \% }\end{array}$ & $\begin{array}{l}\text { 3-year } \\
\text { survival, \% }\end{array}$ & $\begin{array}{l}\mathrm{p} \\
\text { value }\end{array}$ & $\begin{array}{l}\text { 3-year } \\
\text { survival, \% }\end{array}$ & $\mathrm{p}$ value \\
\hline CYFRA 21-1 & & & & 0.67 & & 0.015 \\
\hline$>$ Cutoff point & 102 & 64 & 72.3 & & 60.2 & \\
\hline$\leq$ Cutoff point & 110 & 63.8 & 74.9 & & 78.4 & \\
\hline CEA & & & & 0.09 & & 0.014 \\
\hline$>$ Cutoff point & 59 & 49 & $70.8^{\mathrm{a}}$ & & $41.6^{\mathrm{b}}$ & \\
\hline$\leq$ Cutoff point & 110 & 66.1 & $74.9^{\mathrm{a}}$ & & $79.2^{\mathrm{b}}$ & \\
\hline TMI & & & & 0.73 & & \\
\hline High-risk group & 105 & 63.1 & 75.9 & & 55.7 & 0.0008 vs. low \\
\hline Intermediate-risk group & 110 & 63.5 & 75.0 & & 77.2 & 0.077 vs. high \\
\hline Low-risk group & 122 & 65.1 & 72.1 & & 96.7 & 0.017 vs. low \\
\hline
\end{tabular}

Cutoff point for CYFRA 21-1: $3.3 \mathrm{ng} / \mathrm{ml}$.

${ }^{\text {a }}$ Cutoff point: $6.7 \mathrm{ng} / \mathrm{ml} .{ }^{\mathrm{b}}$ Cutoff point: $9.8 \mathrm{ng} / \mathrm{ml}$.

prised $22.7,42.6$ and $34.7 \%$ of the patients, respectively, showing statistically significant differences in survival rates (table 4). Neither CEA or CYFRA 21-1 levels nor TMI were statistically significant in this study $(\mathrm{p}=0.7320$; fig. 1; table 4). Therefore, alternative cutoff points for CYFRA 21-1 and CEA were investigated to independently assess the prognostic information of these biomarkers. For CYFRA 21-1 none of the cutoff points indicated prognostic value at the adjusted 0.0017 level of statistical sig- nificance (fig. 2). This was also true when only squamous cell carcinomas and adenocarcinomas were analyzed. CEA cutoff points $\geq 9 \mathrm{ng} / \mathrm{ml}$ indicated statistical significance at the adjusted $\alpha$ level ( $p=0.0015)$. However, $<10 \%$ of the patients had CEA levels above this cutoff point (fig. 3). For CEA, no other significant cutoff points were found restricting the patient group to adenocarcinomas or squamous cell carcinomas. 


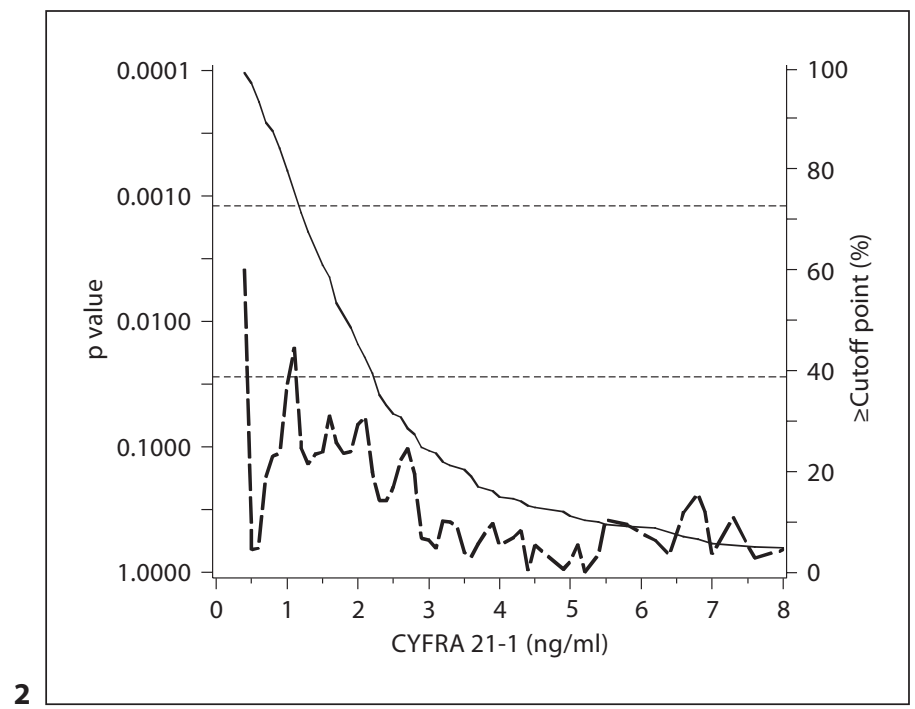

Fig. 2, 3. Evaluation of alternative cutoff points of CYFRA 21-1 (2) and CEA (3) for associations with mortality; solid curve: percentage of patients with values above the corresponding cutoff points;

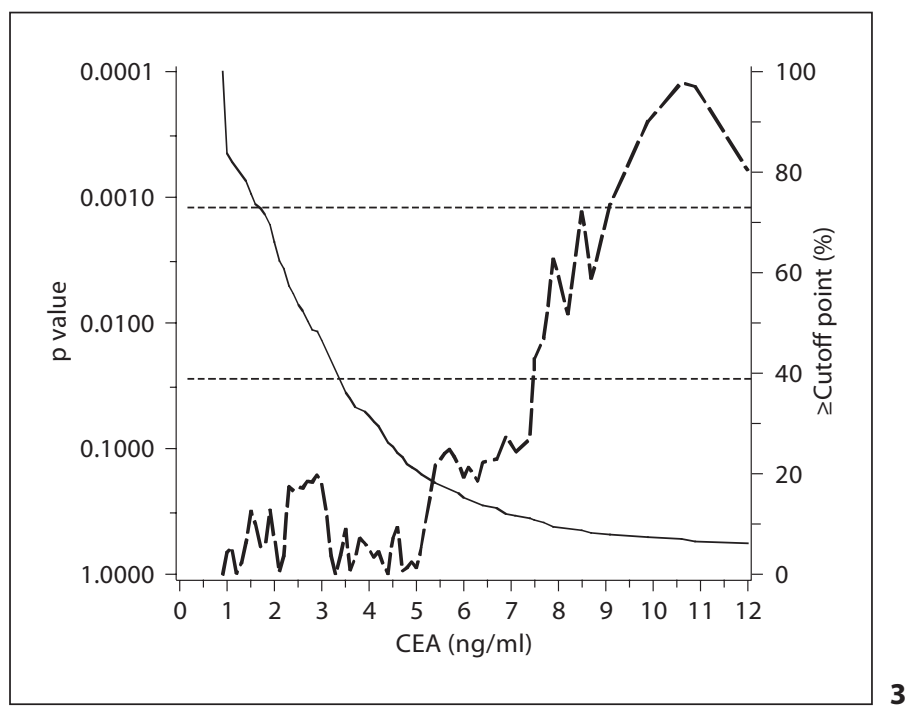

dashed curve: $\mathrm{p}$ values from log-rank test for each cutoff point; lower horizontal dashed line: $p$ value of 0.05 ; upper horizontal line: adjusted $\mathrm{p}$ value [10].

\section{Discussion}

Survival rates for patients suffering from NSCLC are dismal, even for early-stage disease. While surgery is currently the only treatment recommended for NSCLC, evidence accumulates that some patients might benefit from adjuvant therapy $[11,12]$. Prognostic factors such as the TMI might help to separate patients likely to benefit from adjuvant therapy from those who have a good prognosis postoperatively.

Overall survival rates in this study $(74 \%$ for 3 years and $64 \%$ for 5 years) were similar to those reported by Muley et al. [7] and others [13-16]. Two studies reported a survival rate of approximately $80 \%$ at 5 years $[17,18]$, but these studies had a higher percentage of female patients and in one of them [18], patient follow-up was only 36 months versus 110 months in our study. The previously established prognostic factors age and sex $[7,13,17,18]$ were confirmed in this investigation, whereas tumor size or histology were not associated with survival, in accord with the results of Muley et al. [7]. However, the results of this study neither confirmed the association of TMI to survival nor the prognostic significance of CYFRA 21-1. In studies including patients with NSCLC at all stages [19-22] or those restricted to patients with squamous cell carcinomas of the lung $[15,23,24]$, high CYFRA 21-1 levels have been associated with a poorer outcome independent of histology. Most of them used clinical staging to diagnose early-stage NSCLC, leading to bias due to potential misstaging [17, 25-27]. To our knowledge, only two studies on CYFRA 21-1 and CEA levels have been conducted exclusively in pathological stage I patients [7, 18]. Muley et al. [7] demonstrated independent significant prognostic significance for CYFRA 21-1, and Matsuoka et al. [18] revealed CYFRA 21-1 as a significant prognosticator for overall survival but not time to progression.

Although CEA is one of the earliest available biomarkers, its role as a prognosticator for survival in NSCLC remains controversial. The prognostic value of CEA was demonstrated in several studies $[7,25,26,28]$ in contrast to others $[20,29,30]$, which may be due to the heterogeneous histological subtypes. Investigations including a high percentage of patients with squamous cell carcinoma $[20,24]$ found a statistically significant association between elevated preoperative CEA levels and poorer survival, whereas the study by Nisman et al. [23] showed statistical significance only in patients with adenocarcinoma. In our study, statistically significant associations between CEA and survival could only be demonstrated for preoperative CEA levels $>9 \mathrm{ng} / \mathrm{ml}$ or on a continuous scale. The detection of prognostic significance depends on the cutoff point selected. Thus, more detailed examinations covering a range of CEA cutoff points and scales may aid in the detection of associations. Findings from these investigations require external validation since data 
mining of a particular dataset is used to identify the optimal cutoff point, with a high probability of not being exactly replicated in other studies. One reason for the differences in the prognostic values of CYFRA and CEA found across studies could be the incomparability of immunoassays across different assay systems, which is particularly striking when selected cutoff points are used.
For this reason, alternative cutoff points for CEA and CYFRA 21-1 to those recommended by Muley et al. [7] were investigated in this study. Another limitation is the heterogeneity of the patient cohorts. These inconsistencies should be resolved by further external validations, preferably across multiple centers.

\section{References}

1 Parkin DM, Bray F, Ferlay J, Pisani P: Global cancer statistics 2002. CA Cancer J Clin 2005;55:74-108.

2 Jemal A, Murray T, Ward E, et al: Cancer statistics, 2005. CA Cancer J Clin 2005;55:1030.

3 Wittekind Ch, Meyer H-J, Bootz F (eds): UICC: TNM Classification of Malignant Tumours, ed 6. Berlin, Springer, 2002.

4 Smythe WR: Treatment of stage I non-small cell lung carcinoma. Chest 2003;123:181S$187 \mathrm{~S}$.

5 Tsuboi M, Ohira T, Saji H, et al: The present status of postoperative adjuvant chemotherapy for completely resected non-small cell lung cancer (review). Ann Thorac Cardiovasc Surg 2007;13:73-77.

6 Arriagada R, Bergman B, Dunant A, Le Chevalier T, Pignon JP, Vansteenkiste J, International Adjuvant Lung Cancer Trial Collaborative Group: Cisplatin-based adjuvant chemotherapy in patients with completely resected non-small-cell lung cancer. N Engl J Med 2004;350:351-360.

7 Muley T, Dienemann H, Ebert W: CYFRA 21-1 and CEA are independent prognostic factors in 153 operated stage I NSCLC patients. Anticancer Res 2004;24:1953-1956.

8 World Health Organization: Histological Typing of Lung Tumours, ed 2. Geneva, World Health Organization, 1981.

9 Mountain CF: Revisions in the international item for staging lung cancer. Chest 1997;111: 1710-1717.

10 Altman DG, Lausen B, Sauerbrei W, Schumacher M: Dangers of using 'optimal' cutpoints in the evaluation of prognostic factors. J Natl Cancer Inst 1994;86:829-835.

11 Alam N, Darling G, Evans WK, Mackay JA, Shepherd FA: Adjuvant chemotherapy for completely resected non-small cell lung cancer: a systematic review. Crit Rev Oncol Hematol 2006;58:146-155.

12 Booth CM, Shepherd F: Adjuvant chemotherapy for resected non-small cell lung cancer. J Thorac Oncol 2006;1:180-187.
13 Muley T, Dienemann H, Ebert W: Increased CYFRA 21-1 and CEA levels are negative predictors of outcome in p-stage I NSCLC. Anticancer Res 2003;23:4085-4093.

14 Harpole DH, Herndon JE, Young WG, Wolfe WG, Sabiston DC: Stage I nonsmall cell lung cancer. A multivariate analysis of treatment methods and patterns of recurrence. Cancer 1995;76:787-796.

15 Nesbitt JC, Putnam JB, Walsh GL, Roth JA, Mountain CF: Survival in early stage nonsmall cell lung cancer. Ann Thorac Surg 1995;60:466-472.

16 Brundage MD, Davies D, Mackillop WJ: Prognostic factors in non-small cell lung cancer: a decade of progress. Chest 2002;122: 1037-1057.

17 Suzuki H, Ishikawa S, Satoh $\mathrm{H}$, et al: Preoperative CYFRA 21-1 levels as a prognostic factor in c-stage I non-small cell lung cancer. Eur J Cardiothorac Surg 2007;32:648-652.

18 Matsuoka K, Sumitomo S, Nakashima N, Nakajima D, Misaki N: Prognostic value of carcinoembryonic antigen and CYFRA 21-1 in patients with pathological stage I nonsmall cell lung cancer. Eur J Cardiothorac Surgy 2007;32:435-439.

19 Stieber P, Hasholzner U, Bodenmuller H, et al: CYFRA 21-1. A new marker in lung cancer. Cancer 1993;72:707-713.

20 Nisman B, Lafair J, Heching N, et al: Evaluation of tissue polypeptide specific antigen, CYFRA 21-1, and carcinoembryonic antigen in nonsmall cell lung carcinoma: does the combined use of cytokeratin markers give any additional information? Cancer 1998;82: 1850-1859.

21 Pujol J-L, Molinier O, Ebert W, et al: CYFRA 21-1 is a prognostic determinant in nonsmall-cell lung cancer: results of a metaanalysis in 2063 patients. Br J Cancer 2004; 90:2097-2105
22 Pujol JL, Boher JM, Grenier J, Quantin X: CYFRA 21-1, neuron specific enolase and prognosis of non-small cell lung cancer: prospective study in 621 patients. Lung Cancer 2001:31:221-231.

23 Nisman B, Amir G, Lafair J, et al: Prognostic value of CYFRA 21-1, TPS and CEA in different histologic types of non-small cell lung cancer. Anticancer Res 1999;19:3549-3552.

24 Kulpa J, Wójcik E, Reinfuss M, Kolodziejski L: Carcinoembryonic antigen, squamous cell carcinoma antigen, CYFRA 21-1, and neuron-specific enolase in squamous cell lung cancer patients. Clin Chem 2002;48:19311937.

25 Sawabata N, Ohta M, Takeda S, et al: Serum carcinoembryonic antigen level in surgically resected clinical stage I patients with nonsmall cell lung cancer. Ann Thorac Surg 2002;74:174-179.

26 Suzuki K, Nagai K, Yoshida J, et al: Prognostic factors in clinical stage I non-small cell lung cancer. Ann Thorac Surg 1999;67:927932 .

27 Koike T, Tsuchiya R, Goya T, Sohara Y, Miyaoka E: Prognostic factors in 3315 completely resected cases of clinical stage I nonsmall cell lung cancer in Japan. J Thorac Oncol 2007;2:408-413.

28 Kobayashi N, Toyooka S, Soh J, et al: Risk factors for recurrence and unfavorable prognosis in patients with stage I non-small cell lung cancer and a tumor diameter of $20 \mathrm{~mm}$ or less. J Thorac Oncol 2007;2:808-812.

29 Reinmuth N, Brandt B, Semik M, et al: Prognostic impact of CYFRA 21-1 and other serum markers in completely resected nonsmall cell lung cancer. Lung Cancer 2002;36: 265-270.

30 Tsuchiya T, Akamine S, Muraoka M, et al: Stage IA non-small cell lung cancer: vessel invasion is a poor prognostic factor and a new target of adjuvant chemotherapy. Lung Cancer 2007;56:341-348. 